\title{
Penerapan Model Pembelajaran Problem Based Learning untuk Menganalisis Keterampilan Pemecahan Masalah Siswa SMP pada Materi Cahaya
}

\author{
A.R Sinensis", T. Firdaus, T. Hardila, Nopitasari, dan N. Saiputri \\ Prodi Pendidikan Fisika STKIP Nurul Huda, Oku Timur. Sumatera Selatan, Indonesia \\ *Email:arini@stkipnurulhuda.ac.id
}

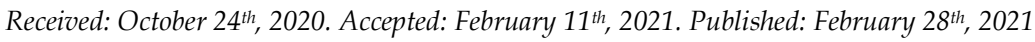

\begin{abstract}
Abstrak
Tantangan pendidikan abad 21 adalah menyiapkan sumber daya manusia yang wajib memiliki keterampilan, salah satunya yaitu pemecahan masalah. Model pembelajaran Problem Based Learning (PBL) dipandang efektif dalam melatih keterampilan pemecahan masalah karena memiliki karakterisitik konstruktivis dengan pembelajaran IPA. Tujuan penelitian ini adalah menganalisis keterampilan pemecahan masalah siswa pada materi Cahaya melalui pembelajaran PBL. Metode penelitian yang digunakan adalah kuantitatif dengan analisis deskriptif. Sampel penelitian adalah 22 siswa SMP Terpadu Tanah Merah kelas IX. Teknik pengumpulan data menggunakan lembar observasi keterampilan pemecahan masalah. Hasil penelitian menunjukkan bahwa terdapat peningkatan keterampilan pemecahan masalah siswa dari percobaan pertama sampai ke tiga. Peningkatan dengan persentase tertinggi yaitu pada percobaan ke tiga dengan indikator melakukan pemecahan masalah/penyelidikan sebesar 90,9\%. Data rata-rata tiap indikator pemecahan masalah menunjukkan siswa dapat memahami masalah sebesar 80,78\%, mengumpulkan data sebesar 69,63\%, melaksanakan pemecahan masalah/penyelidikan sebesar 78,46\%, dan membuat kesimpulan sebesar $66,67 \%$. Hasil tersebut menunjukkan model Problem Based Learning dapat digunakan sebagai kontruksi
\end{abstract}


pembelajaran IPA dalam meningkatkan keterampilan pemecahan masalah.

\begin{abstract}
The challenge of $21^{\text {st }}$ century education is to prepare human resources who are required to have skills, one of which is problem solving. The Problem Based Learning (PBL) learning model is considered effective in training problem-solving skills because it has constructivist characteristics with science learning. The purpose of this study was to analyze students' problem solving skills in the Light material through PBL learning. The research method used is quantitative with descriptive analysis. The research sample was 22 Tanah Merah Integrated Junior High School students grade IX. The data collection technique used the observation sheet of problem solving skills. The results showed that there was an increase in students' problem solving skills from the first to the third experiment. The increase with the highest percentage was in the third experiment with indicators of problem solving/ investigation by $90.9 \%$. The average data for each problem solving indicator shows that students can understand the problem by $80.78 \%$, collect data by $69.63 \%$, carry out problem solving/investigation by $78.46 \%$, and make conclusions by $66.67 \%$. These results indicate that the Problem Based Learning model can be used as a science learning construction in improving problem solving skills. @2021PERJ
\end{abstract}

Keywords: Problem Based Learning; Problem Solving Skill; Science Learning.

\section{PENDAHULUAN}

Tantangan kehidupan di masa mendatang menjadi salah satu alasan pendidik untuk mengembangkan keterampilan siswa. Pendidik dituntut untuk memberikan inovasi dalam menerapkan strategi, model, dan metode yang digunakan di sekolah untuk meningkatkan dan mengasah keterampilan siswa.
Pembelajaran abad 21 ditandai dengan Student Center Learning (SCL) dengan empat keterampilan yang harus dikembangkan, yaitu komunikasi, kolaborasi, berpikir kritis dan pemecahan masalah, serta kreativitas dan inovasi. Pembelajaran abad 21 memiliki empat prinsip utama, yaitu student center, collaborative learning, contextual, dan terintegrasi dalam kehidupan bermasyarakat 
(Zubaidah, 2016). Dimensi keterampilan berdasarkan standar kompetensi lulusan siswa tingkat SMP adalah kemampuan berpikir kreatif, produktif, kritis, mandiri, kolaboratif, dan komunikatif (Permendikbud, 2016). Berdasarkan hal tersebut, upaya dalam peningkatan keterampilan dan kemampuan dalam proses pembelajaran harus dilakukan.

Kenyataannya, hingga saat ini masih terdapat pembelajaran di sekolah yang belum mengembangkan keterampilan sebagai bekal siswa untuk untuk masa depan. Pembelajaran di kelas hanya menekankan pada metode ceramah dari guru, tanya jawab soal, dan diskusi. Proses pembelajaran IPA/Fisika jarang melibatkan pengetahuan awal siswa. Pembelajaran IPA di kelas cenderung pada menghafal rumus dan mencatat materi.

Berdasarkan hasil interview, siswa SMP Terpadu Tanah Merah memberikan informasi bahwa fisika dianggap pembelajaran yang sulit dipahami. Hal ini disebabkan banyaknya persamaan matematis dan beberapa konsep yang abstrak. Selain itu, pembelajaran yang dilakukan di kelas kurang memotivasi siswa untuk meningkatkan rasa ingin tahu.

Temuan yang lain dari interview kepada siswa SMP Terpadu Tanah Merah adalah hasil belajar hanya diukur dari nilai akademik yaitu hasil ulangan harian dan ulangan umum. Berdasarkan hasil observasi di sekolah tersebut juga ditemukan bahwa siswa cenderung pasif dan tidak responsif dalam proses pembelajaran, seperti kurangnya rasa ingin bertanya dan mengemukakan pendapat. Kemandirian siswa dalam belajar yang kurang memberikan dampak pada hasil belajar yang masuk pada kriteria rendah.

Proses pembelajaran di dalam kelas sangat memengaruhi kualitas pembelajaran dan berdampak pada pemahaman konsep serta minat siswa dalam belajar (Mashuri et al., 2019). Oleh karena itu dibutuhkan proses pembelajaran yang efektif untuk meningkatkan minat dan motivasi siswa dalam belajar.

Pembelajaran IPA didesain berdasarkan kurikulum dan silabus dengan tujuan merubah pola pikir, sikap, dan keterampilan siswa (Lukum, 2015). Salah satu upaya untuk meningkatkan proses belajar mengajar IPA adalah dengan merekonstruksi pembelajaran melalui model Problem Based Learning (PBL) (Fathurrohman, 2015).

Model Problem Based Learning (PBL) menekankan pada pusat masalah, dari tujuan instruksional hingga perilaku siswa, metode dan teknik yang akan digunakan, hingga proses pengukuran dan evaluasi yang akan dilakukan (Bayrak \& Gürses, 2020). Isrok'atun dan Rosmala (2018) menyatakan bahwa pembelajaran PBL memberikan kesempatan siswa untuk berlatih dalam memecahkan masalah. 
Menurut Abdullah (2017) model PBL diawali dengan menyajikan masalah, rumusan pertanyaan, memfasilitasi penyelidikan, dan membuka tanya jawab antar siswa untuk memecahkan masalah dan menerapkan konsep dan prinsip. Prinsip pada model PBL yaitu siswa tidak hanya dibekali dengan pengetahuan saja, akan tetapi dapat menerapkan konsep dan pengetahuan dalam situasi nyata. Pembelajaran PBL biasanya dilakukan secara kelompok, dan diakhiri dengan evaluasi dan review (Effendi et al., 2019).

Fisika sebagai salah satu bagian dari IPA sangat berkontribusi dalam berkembanganya ilmu pengetahuan dan teknologi. Pembelajaran fisika di sekolah dapat menjadi materi yang penting untuk perkembangan keilmuan pada tingkat selanjutnya. Fenomena fisika juga mudah ditemui dalam situasi dunia nyata. Siswa sering mengalami dan melihat fenomena fisika tanpa menyadari bahwa konsep tersbut adalah bagian dari fisika. Oleh karena itu, hal-hal yang berkaitan dengan fenomena fisika dalam kehidupan sehari-hari dapat dipecahkan dan dianalisis melalui model PBL.

PBL sangat sesuai dengan karakteristik konstruktivis dalam pembelajaran IPA yang menekankan aspek metode/proses ilmiah dan sikap ilmiah. Melalui PBL, keterampilan sains siswa dapat ditingkatkan. Siswa melakukan pengamatan langsung, penyelidikan dengan orientasi masalah.

Penerapan PBL dalam pembelajaran fisika di sekolah juga meningkatkan kemampuan siswa dalam menguasai konsep. Selain itu, melalui PBL siswa cenderung aktif karena keterlibatan antar siswa untuk saling berinteraksi, komunikasi, berargumentasi dan berdiskusi untuk mencari solusi memecahkan masalah hingga membuat kesimpulan.

Implementasi model PBL dapat diintegrasikan dengan kegiatan percobaan. Pada saat percobaan, siswa dibimbing oleh guru untuk mengaitkan konsep yang telah dipelajari untuk memecahkan masalah (Hastuti et al., 2017). Siswa yang mengalami pembelajaran dengan model PBL tidak hanya sekedar memperoleh informasi pengetahuan melainkan dapat membangun konsep dan membentuk struktur pengetahuan yang utuh (Prima \& Kaniawati, 2011).

Tujuan penelitian ini adalah mengimplementasikan model Problem Based Learning (PBL) untuk menganalisis keterampilan pemecahan masalah siswa SMP Terpadu Tanah Merah. Melalui penelitian ini, siswa dapat mengembangkan keterampilan pemecahan masalah fisika, dan guru memeroleh informasi dalam penerapan model PBL untuk meningkatkan keterampilan pemecahan masalah siswa. 


\section{METODE}

Metode penelitian ini adalah kuantitatif dengan analisis deskriptif. Sampel dalam penelitian ini adalah 22 siswa kelas IX SMP Terpadu Tanah Merah Oku Timur. Tahapan penelitian dengan implementasi Problem Based Learning (PBL) ditunjukkan pada Gambar 1.

\begin{tabular}{|c|c|c|}
\hline $\begin{array}{l}\text { Perencanaan } \\
\text { •Observasi dan } \\
\text { interview di sekolah } \\
\text { yang akan diteliti } \\
\text { untuk mendapatkan } \\
\text { informasi terkait } \\
\text { pembelajaran IPA } \\
\text { (Fisika) yang telah } \\
\text { dilakukan. Pada tahap } \\
\text { ini ditemukan masalah } \\
\text { yang selanjutnya } \\
\text { dilakukan } \\
\text { perencanaan untuk } \\
\text { memecahkan masalah } \\
\text { tersebut. }\end{array}$ & $\begin{array}{l}\text { Pelaksanaan } \\
\text { - Implementasi } \\
\text { model PBL pada } \\
\text { materi Cahaya dan } \\
\text { melakukan proses } \\
\text { pengamatan untuk } \\
\text { mengetahui } \\
\text { keterampilan } \\
\text { pemecahan } \\
\text { masalah yang } \\
\text { ditingkatkan pada } \\
\text { tiap-tiap } \\
\text { percobaan. }\end{array}$ & $\begin{array}{l}\text { Evaluasi } \\
\text { - Evaluasi } \\
\text { penerapan model } \\
\text { PBL terhadap } \\
\text { keterampilan } \\
\text { pemecahan } \\
\text { masalah siswa, } \\
\text { dan penarikan } \\
\text { kesimpulan } \\
\text { berdasarkan data } \\
\text { yang telah } \\
\text { dianalisis. }\end{array}$ \\
\hline
\end{tabular}

Gambar 1. Tahapan Implementasi Model PBL

Teknik pengumpulan data kesimpulan. Teknik analisis data menggunakan interview dan yang digunakan adalah analisis observasi. Interview dilakukan deskriptif dengan menguraikan dan terhadap siswa untuk mengidentifikasi permasalahan dalam belajar fisika/IPA di kelas. Observasi terhadap pembelajaran dilakukan di awal penelitian untuk mengidentifikasi masalah pembelajaran dan saat penerapan model PBL. Lembar observasi pemecahan masalah digunakan sebagai instrumen untuk menganalisis peningkatan keterampilan pemecahan masalah setelah penerapan model PBL. Indikator yang digunakan adalah siswa dapat: 1) memahami masalah, 2) mengumpulkan data, 3) melaksanakan pemecahan masalah/penyelidikan, 4) membuat memberikan keterangan suatu data, persoalan atau keadaan. Penarikan kesimpulan berdasarkan pada data yang telah dikumpulkan (Hasan, 2001). Model PBL diterapkan melalui kegiatan percobaan tentang sifat-sifat cahaya, penguraian cahaya, dan pembentukan bayangan pada cermin datar. Ketiga kegiatan tersebut dilengkapi dengan lembar kegiatan siswa (LKPD) berbasis pemecahan masalah dan proses pembelajaran diobservasi dengan menggunakan lembar observasi/pengamatan pemecahan masalah. Sintaks pembelajaran dengan model PBL dapat lihat pada Tabel 1. 
Tabel 1. Sintaks pembelajaran model Problem Based Learning (PBL)

\begin{tabular}{|c|c|c|}
\hline Fase & Kegiatan Guru & Kegiatan Siswa \\
\hline Orientasi masalah & $\begin{array}{l}\text { Menjelaskan tujuan } \\
\text { pembelajaran, menyajikan } \\
\text { masalah yang berkaitan } \\
\text { dengan kehidupan sehari-hari } \\
\text { serta memotivasi siswa untuk } \\
\text { terlibat dalam kegiatan } \\
\text { pemecahan masalah. }\end{array}$ & $\begin{array}{l}\text { Mendengarkan penjelasan } \\
\text { dari guru dan ikut terlibat } \\
\text { dalam aktivitas pemecahan } \\
\text { masalah }\end{array}$ \\
\hline $\begin{array}{l}\text { Mengorganisasikan } \\
\text { siswa untuk } \\
\text { menyelesaikan } \\
\text { masalah }\end{array}$ & $\begin{array}{l}\text { Membimbing / mengatur } \\
\text { siswa untuk berkelompok dan } \\
\text { memberikan demonstrasi } \\
\text { mengenai gambaran materi } \\
\text { permasalahan }\end{array}$ & $\begin{array}{l}\text { Bergabung sesuai dengan } \\
\text { kelompok serta memahami } \\
\text { gambaran permasalahan } \\
\text { yang dijelaskan guru }\end{array}$ \\
\hline $\begin{array}{l}\text { Membimbing } \\
\text { penyelidikan } \\
\text { individu atau } \\
\text { kelompok }\end{array}$ & $\begin{array}{l}\text { Membimbing siswa dalam } \\
\text { melakukan rancangan } \\
\text { percobaan dan membimbing } \\
\text { dalam pengisian LKS }\end{array}$ & $\begin{array}{l}\text { Melakukan } \\
\text { pengamatan/percobaan dan } \\
\text { mengisi LKS yang telah } \\
\text { disiapkan }\end{array}$ \\
\hline $\begin{array}{l}\text { Mengembangkan } \\
\text { dan menyajikan } \\
\text { hasil karya }\end{array}$ & $\begin{array}{l}\text { Melakukan ulasan terhadap } \\
\text { proses dan hasil pembelajaran } \\
\text { siswa }\end{array}$ & $\begin{array}{l}\text { Siswa mereview kembali } \\
\text { hasil pembelajaran }\end{array}$ \\
\hline $\begin{array}{l}\text { Menganalisis dan } \\
\text { mengevaluasi } \\
\text { proses pemecahan } \\
\text { masalah }\end{array}$ & $\begin{array}{l}\text { Menganalisis proses } \\
\text { pembelajaran serta } \\
\text { mengevaluasi hasil belajar } \\
\text { siswa }\end{array}$ & $\begin{array}{l}\text { Siswa merefleksikan } \\
\text { terhadap pemahaman hasil } \\
\text { pembelajaran }\end{array}$ \\
\hline
\end{tabular}

\section{HASIL DAN PEMBAHASAN}

Hasil analisis lembar observasi terhadap keterampilan pemecahan masalah siswa pada materi cahaya disajikan pada Gambar 2. Berdasarkan hasil analisis data jika ditinjau dari hasil rata-rata tiap indikator pemecahan masalah dari percobaan pertama sampai ke tiga yaitu: memahami masalah sebesar $80,78 \%$, mengumpulkan data $69,63 \%$, melaksanakan pemecahan masalah atau penyelidikan 78,46, dan membuat kesimpulan $66,67 \%$.
Hasil dari Implementasi pembelajaran model PBL materi Cahaya memberikan dampak positif terhadap peningkatan keterampilan memecahkan masalah siswa pada indikator memahami masalah dan melakukan penyelidikan. Pada percobaan ke tiga tentang menentukan pembetukan bayangan pada cermin datar, siswa menggambarkan permasalahan dalam kehidupan sehari-hari seperti kegiatan bercermin. Hal ini sesuai dengan pendapat Fakhriyah, (2014) yang menyatakan bahwa masalah yang diajukan dalam penerapan model PBL harus nyata, kontekstual 
dan mudah ditemui oleh siswa dalam fenomena kehidupan seharihari. Kegiatan memahami masalah membiasakan siswa dalam melakukan pemecahan masalah yang memengaruhi kemampuan tingkat tinggi siswa (Supiandi \&
Julung, 2016). Selain itu, dengan memberikan/menyajikan masalah yang berkaitan dengan fenomena sehari-hari dapat melatih siswa untuk memecahkan masalah dan menemukan solusi alternatif (Fariyani et al., 2020).

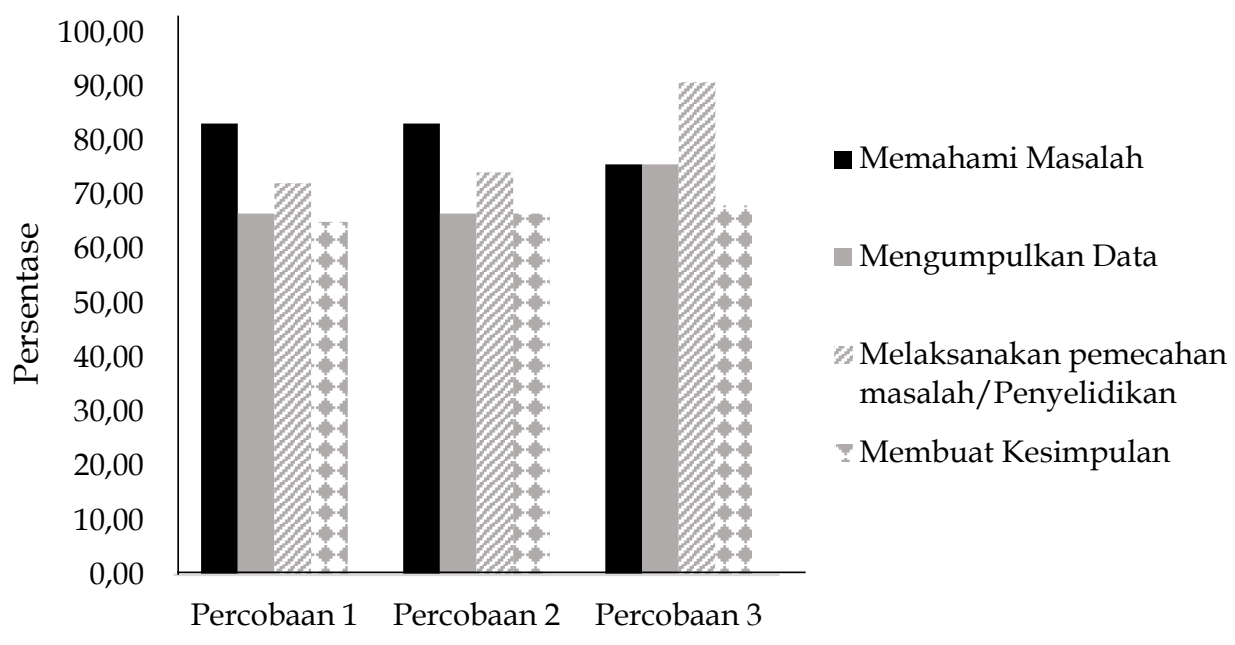

Gambar 2. Hasil Analisis Keterampilan Pemecahan Masalah Siswa

Peningkatan keterampilan pemecahan masalah pada percobaan ke tiga terjadi karena siswa telah berpengalaman dalam percobaan sebelumnya. Permasalahan yang tersedia pada lembar kerja siswa (LKPD) didesain untuk mengarahkan siswa dalam memecahkan masalah, sehingga mempengaruhi tingkat pemahaman siswa terhadap masalah. Model PBL juga dapat memacu siswa untuk lebih aktif belajar dan meningkatkan hasil belajar psikomotorik (Rerung et al., 2017; Jiniarti et al., 2015; Supiandi \& Julung, 2016). Penelitian ini menunjukkan hasil serupa, yaitu terdapat peningkatan keterampilan siswa dalam memecahkan masalah atau melakukan penyelidikan pada percobaan ke tiga. Pada proses ini siswa aktif dalam kegiatan penyelidikan.

Peningkatan terjadi pada indikator membuat kesimpulan pada tiap-tiap percobaan. Faktor yang memengaruhi peningkatan ini adalah siswa dibimbing guru untuk mengemukaan pendapat tentang hasil pekerjaan yang telah dilakukan dan melakukan evaluasi dari pembelajaran yang telah dilakukan. Siswa harus berkomunikasi secara jelas baik 
dengan tulisan maupun lisan dan juga harus saling mendengarkan dan mempertimbangkan sudut pandang satu sama lain (Trilling \& Fadel, 2010; Supiandi, 2016; Sumiantar et al, 2019).

Model PBL juga melatih keterampilan kolaborasi siswa. Ketika melakukan kegiatan pemecahan masalah dalam percobaan, siswa saling berinteraksi (diskusi) satu sama lain untuk menemukan solusi. Kerja kelompok yang dilakukan selama percobaan menjadikan pembelajaran PBL sebagai proses kolaboratif (Dolmans et al., 2005).

Keterampilan komunikasi juga dilatih dalam pembelajaran model PBL. Selama kegiatan percobaan, terjadi komunikasi antara siswa satu dengan yang lainnya untuk mendiskusikan permasalahan yang dihadapi dalam kelompok. Penerapan model PBL juga dapat membantu siswa dalam mengkontekstualisasi pengetahuan tentang konten dan mentransfer pengetahuan (Hung, 2011). Pada saat siswa telah terlatih dalam keterampilan pemecahan masalah, kolaborasi, dan komunikasi maka siswa akan lebih mudah dalam menghadapi tantangan abad ke-21.

\section{KESIMPULAN}

Berdasarkan hasil analisis data dapat disimpulkan bahwa terdapat peningkatan keterampilan pemecahan masalah dengan indiator memahami masalah, mengumpulkan data, melakukan penyelidikan, dan membuat kesimpulan pada percobaan pertama, ke dua dan ke tiga. Peningkatan dengan persentase tertinggi terdapat pada percobaan ke tiga, yaitu pada indikator melakukan pemecahan masalah/penyelidikan. Penerapan model PBL dalam pembelajaran IPA dapat membekali siswa dengan keterampilan pemecahan masalah untuk menghadapi tantangan abad ke 21.

\section{DAFTAR PUSTAKA}

Abdullah, R. 2017. Pembelajaran Sainstifik untuk Implementasi Kurikulum 2013. Jakarta: Bumi Aksara

Bayrak, R., \& Gürses, A. 2020. Teaching of the Subject of Solids Through Problem-Based Learning Approach. World Journal of Education, 10(3), 47. https://doi.org/10.5430/wje.v 10n3p47

Dolmans, D. H. J. M., De Grave, W., Wolfhagen, I. H. A. P., \& Van Der Vleuten, C. P. M. 2005. Problem-based learning: Future challenges for educational practice and research. Medical Education, 39(7), 732-741. https://doi.org/10.1111/j.136 5-2929.2005.02205.x

Effendi, E., Sugiarti, M., \& Gunarto, W. 2019. Penerapan Model Problem Based Learning dan 
Model Project Based Learning terhadap Hasil Belajar Siswa. Science and Physics Education Journal (SPEJ), 2(2), 42-51. https://doi.org/10.31539/spej .v2i2.643

Fakhriyah, F. 2014. Penerapan problem based learning dalam upaya mengembangkan kemampuan berpikir kritis mahasiswa. Jurnal Pendidikan IPA Indonesia, 3(1), 95-101. https://doi.org/10.15294/jpii. v3i1.2906

Fariyani, Q., Mubarok, F. K., Masfu'ah, S., \& Syukur, F. 2020. Pedagogical Content Knowledge of Pre-service Physics Teachers. Jurnal Ilmiah Pendidikan Fisika Al-Biruni, 9(1), 99-107.

https://doi.org/10.24042/jipf albiruni.v9i1.3409

Hastuti, A., Sahidu, H., \& Gunawan, G. 2017. Pengaruh Model PBL Berbantuan Media Virtual Tehadap Kemampuan Pemecahan Masalah Fisika. Jurnal Pendidikan Fisika Dan Teknologi, 2(3), 129. https://doi.org/10.29303/jpft. v2i3.303

Hung, W. 2011. Theory to reality: A few issues in implementing problem-based learning. Educational Technology Research and Development, 59(4), 529-552. https://doi.org/10.1007/s1142 3-011-9198-1

Lukum, A. 2015. Evaluasi Program

$\begin{array}{lrr}\begin{array}{l}\text { Pembelajaran IPA } \\ \text { Menggunakan }\end{array} & \text { SMP } \\ \text { Model } \\ \text { Countenance } & \text { Stake. } & \text { Jurnal } \\ \text { Penelitian Dan } & \text { Evaluasi } \\ \text { Pendidikan, 19(1), } & 25-37 . \\ \text { https://doi.org/10.21831/pep. } \\ \text { v19i1.4552 }\end{array}$

Mashuri, S., Djidu, H., \& Ningrum, R. K. 2019. Problem-based learning dalam pembelajaran matematika: Upaya guru untuk meningkatkan minat dan prestasi belajar siswa. Pythagoras: Jurnal Pendidikan Matematika, 14(2), 112-125. https://doi.org/10.21831/pg. v14i2.25034

Permendikbud. 2016. Standar Kompetensi Luliusan dan Pendidikan Dasar dan Menengah (Issue May).

Prima, E. C., \& Kaniawati, I. 2011. Penerapan Model Pembelajaran Problem Based Learning Dengan Pendekatan Inkuiri Untuk Meningkatkan Keterampilan Proses Sains Dan Penguasaan Konsep Elastisitas Pada Siswa Sma. Jurnal Pengajaran Matematika Dan Ilmu Pengetahuan Alam, 16(1), 179. https://doi.org/10.18269/jpm ipa.v16i1.279

Rerung, N., Sinon, I. L. S., \& Widyaningsih, S. W. 2017. Penerapan Model Pembelajaran Problem Based Learning (PBL) untuk meningkatkan Hasil Belajar. Jurnal Ilmiah Pendidikan Fisika 
Al-BiruNi, 06(April), 47-55. https://doi.org/10.24042/jipf

Supiandi, M. I., \& Julung, H. 2016.

Pengaruh Model Problem

Based Learning (PBL) terhadap Kemampuan Memecahkan Masalah dan Hasil Belajar Kognitif Siswa Biologi SMA. JPS (Jurnal Pendidikan Sains), 4(2), 60-64. https://doi.org/10.17977/jps. v4i2.8183

Trilling, B., \& Fadel, C. 2010. 21 ${ }^{\text {st }}$ Century Skills: Learning for
Life in Our Times. Choice Reviews Online, 47(10), 47-578847-5788.

https://doi.org/10.5860/choic e.47-5788

Zubaidah, S. 2016. Keterampilan abad ke-21: Keterampilan yang diajarkan melalui pembelajaran. Di Seminar Nasional Pendidikan dengan Tema "isu-isu strategis pembelajaran MIPA Abad (Vol. 21, No. 10). 